Хомич Іванна

викладач кафедри вікової та педагогічної психології Рівненського державного гуманітарного університету http://orcid.org/0000-0001-8930-6572 DOI https://doi.org/10.35619/praprv.v1i15.198

\title{
ОСОБЛИВОСТІ ПРОЯВУ \\ ОСОБИСТІСНИХ ХАРАКТЕРИСТИК МОЛОДШИХ ШКОЛЯРІВ ІЗ РІЗНИМ СОЦІОМЕТРИЧНИМ СТАТУСОМ У КЛАСІ
}

\begin{abstract}
Анотація. Стаття присвячена дослідженню особливостей прояву моральних характеристик молодших школярів в залежності від сочіометричного статусу в класі 3 урахуванням наукових підходів до вказаної проблеми. В ході експериментального дослідження підтвердилася гіпотеза про ймовірний вплив означеної групуючої змінної (соиіометричного статусу в класі) на рівень вираженості інтегральних особистісних факторів молодших школярів, а саме факторів «морально-ціннісного відношення» та «ціннісного відношення до справ, обов'язків та інших людей». Вказані фактори найвищих середніх значень досягають у категорії молодших школярів з високим сочіометричним статусом в класі («зірки»), демонструючи пік найнижчих середніх значень у категоріі досліджуваних з низьким сочіометричним статусом в класі («ізольовані»). Це означає, щуо значення усіх психологічних шкал, щзо структурно і змістовно визначають специфіку даних інтегральних особистісних факторів, лінійно зростають від категорії досліджуваних $з$ найнижчим соиіометричним статусом в класі до категорії досліджуваних з найвищим соиіометричним статусом, що свідчить про зорієнтованість представників з найвищим соціометричним статусом у класі на морально-етичні цінності у поведінці.

Ключові слова: молодший школяр, особистісні характеристики, сочіометричний статус, особистісні фактори, моральні норми, морально-ціннісне відношення, иіннісне відношення до справ.
\end{abstract}

Постановка проблеми. У сучасному освітньому середовищі $\epsilon$ безліч малодосліджених проблем. Одним із таких вважаємо питання особливостей особистісних характеристик молодших школярів із різним соціометричним статусом у класі. Наше дослідження спрямоване на перевірку гіпотези про ймовірний вплив означеної групуючої змінної (соціометричного статусу) на рівень вираженості інтегральних особистісних факторів молодших школярів, a саме факторів «морально-ціннісного відношення»; «особистісного самоствердження»; «ціннісного відношення до справ, обов'язків та інших людей»; «емоційно-ціннісної направленості»; «особистісного самоконтролю»; «відкритості до світу».

Аналіз останніх досліджень 3 проблеми. Питання особистісних характеристик i соціометричного статусу людини вивчалися в першу чергу у працях Коломінського, Я. Л. (2003), Хлибової, С.В. (2009), Кона, І.С. (2003) та ін. Багато дослідників відзначають, що розвиток сучасних дітей відбувається в зовсім іншому середовищі, ніж кілька десятиліть тому, через зміну простору дитинства і нових умов його функціонування. Зокрема, Фельдштейн, Д.І. (2011) виділив низку проблем, безпосередньо пов'язаних із соціалізацією молодших школярів, зокрема - відсутність соціальної компетентності, безпорадність у відносинах з однолітками, підвищення схильності до агресії, негативна динаміка культурних і соціально-ціннісних орієнтацій школярів, коли емоційні та моральні цінності - чутливість, толерантність, вміння співпереживати займають останні місця в цій ієрархії.

Коломінський, Й. Л. (2003) розуміє особистісні стосунки як особисто значуще, образне, емоційне та інтелектуальне відображення людьми один одного. У системі стосунків 3 однолітками дитина розвиває цілий ряд почуттів, що характеризують іiі як вже соціалізовану людину, яка прагне до самоствердження і конкуренції з іншими, займаючи 
певний статус у групі.

Питання соціалізації особистості детально розглядається в гуманітарних науках, особливо в соціології та психології. Кон, І. С. (2003) визначає соціалізацію як вплив навколишнього середовища в цілому, включаючи особистість в суспільне життя, навчаючи іï розуміти культуру, поведінку в групах, стверджуючи себе і виконуючи різні соціальні ролі та займаючи певну позицію у групі.

Андрєєва, Г.М. (2014) розуміє соціальну позицію як індивідуальну асиміляцію соціального досвіду, і в той же час процес активного відтворення індивідуальною системою соціальних зв'язків, їі діяльність у виконанні дій та включення до соціального середовища, входження до групи.

За словами Мудрика, В.А. (2000) соціальний статус повязаний із розвитком i самореалізацією людини в процесі асиміляції і відтворення культури, що відбувається у взаємодії зі спонтанними, відносно керованими і цілеспрямовано створеними умовами життя на всіх вікових етапах.

Процес формування системи цінностей має свою специфіку у молодшому шкільному віці, що необхідно враховувати у педагогічному процесі. У нашій роботі розглянемо психологічні механізми моральної поведінки в залежності від соціального статусу молодшого школяра у класі.

Мета статті. Метою статті $є$ аналіз прояву особистісних характеристик молодших школярів із різним соціометричним статусом у класі на основі компонентних складових факторної структури особистості (інтегральних особистісних факторів) з урахуванням наукових підходів до вказаної проблеми. Згідно із сформульованою метою нашими завданнями є: аналіз останніх публікацій із теми нашої роботи та здійснення емпіричного аналізу вказаної проблеми.

Виклад основного матеріалу дослідження. Провідною потребою молодших школярів $\epsilon$ потреба в спілкуванні та розумінні. Безумовний авторитет дорослого поступово втрачається, однолітки стають все більш важливими для дитини, а роль дитячого колективу зростає. Якщо для дошкільнят вибір друзів обумовлювався зовнішніми причинами, то молодший школяр починає звертати увагу на якості особистості своїх однолітків і вважати друзями тих, хто відповідає на його прохання і поділяе його інтереси. Особливістю соціалізації молодших школярів є процес, де головна роль відводиться не сім'ї, а шкільному середовищу. Соціалізацію учня можна спостерігати в його поведінці 3 найближчим шкільним оточенням, вмінні поводитися в суспільстві та у його ціннісних орієнтаціях.

Дослідження проводилось на базі Рівненської гімназії «Гармонія», Рівненської класичної гімназії «Престиж» (м. Рівне), Луцьких загальноосвітніх шкіл I-III ступенів №5 і №8 (м. Луцьк) та Тернопільської загальноосвітньої школи I-III ступенів №19 (м. Тернопіль). Досліджуваними стали учні перших-четвертих класів у кількості 189 осіб.

У попередніх доробках ми виділили факторну модель особистісних характеристик молодших школярів. В структуру даної моделі увійшло шість інтегральних факторів: «морально-ціннісного відношення»; «особистісного самоствердження»; «ціннісного відношення до справ, обов'язків та інших людей»; «емоційно-ціннісної направленості»; «особистісного самоконтролю»; «відкритості до світу». Специфічні особливості вказаних інтегральних особистісних факторів молодших школярів виступають особистісними предикторами розвитку їх соціально-психологічної компетентності у сфері нормовідповідності власної поведінки. Попередня стаття була спрямована на визначення особливостей прояву особистісних характеристик молодших школярів залежно від їхнього віку, в даній роботі розглянемо залежність особистісних характеристик молодших школярів від соціометричного статусу в класі.

Таким чином, в ході реалізації даного етапу дослідження перевірялась гіпотеза про ймовірний вплив означеної групуючої змінної (соціометричного статусу в класі) на рівень вираженості інтегральних особистісних факторів молодших школярів.

Перейдемо до аналізу результатів порівняння середніх значень вираженості особистісних факторів досліджуваних, диференційованих за критерієм їх соціометричного 
статусу в класі. Як і в попередніх випадках, при подальшій інтерпретації виявлених тенденцій залишимо поза увагою детального аналізу ті відмінності у середніх значеннях вираженості особистісних факторів молодших школярів, які не мають статистично значущого характеру. Отож, залежно від соціометричного статусу в класі середні значення вираженості особистісних факторів молодших школярів розподілилися наступним чином (див. Табл. 1).

Таблиця 1

Відмінності у середніх значеннях вираженості особистісних факторів досліджуваних залежно від їх соціометричного статусу в класі

\begin{tabular}{|c|c|c|c|c|c|c|c|}
\hline \multirow{2}{*}{\multicolumn{2}{|c|}{ Соціометричний статус в класі }} & \multicolumn{6}{|c|}{ Особистісні фактори } \\
\hline & & 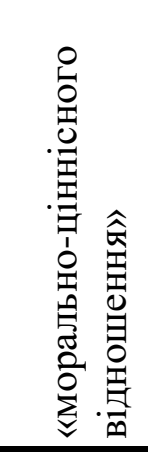 & 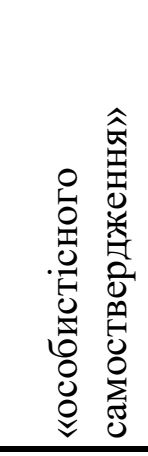 & 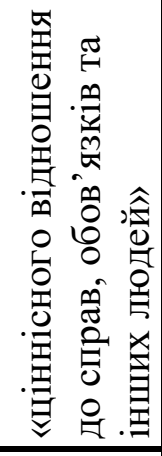 & 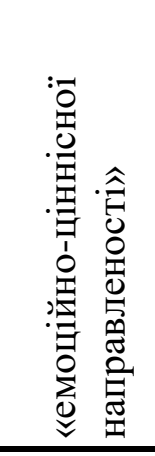 & 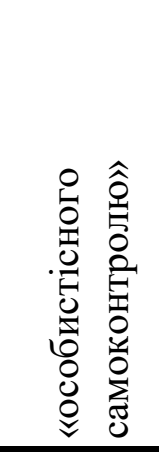 & 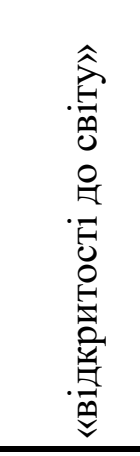 \\
\hline \multirow{2}{*}{ «ізольовані» } & Середнє значення & $-0,1882$ & 0,2342 & $-0,2996$ & $-0,0094$ & $-0,1833$ & $-0,0251$ \\
\hline & Станд. відхилення & 1,0443 & 0,9489 & 1,0075 & 1,1040 & 1,0310 & 1,0665 \\
\hline \multirow{2}{*}{ «прийняті» } & Середнє значення & $-0,1276$ & $-0,2522$ & $-0,1309$ & $-0,0587$ & $-0,1170$ & $-0,0500$ \\
\hline & Станд. відхилення & 1,0018 & 1,0864 & 1,2089 & 1,0748 & 1,0912 & 0,9933 \\
\hline \multirow{2}{*}{ «бажані» } & Середнє значення & 0,1304 & 0,0001 & 0,1836 & 0,0064 & 0,2407 & 0,0924 \\
\hline & Станд. відхилення & 0,9433 & 0,9385 & 0,8624 & 0,8097 & 0,9318 & 0,9916 \\
\hline \multirow{2}{*}{ «зірки» } & Середнє значення & 0,2705 & 0,1467 & 0,3402 & 0,1001 & 0,1150 & 0,0006 \\
\hline & Станд. відхилення & 1,0049 & 0,9559 & 0,6081 & 1,0212 & 0,8780 & 1,0125 \\
\hline \multicolumn{2}{|c|}{ Рівень статистичної значущості } & 0,046 & 0,850 & 0,035 & 0,593 & 0,111 & 0,778 \\
\hline
\end{tabular}

3 огляду на табличні дані можна стверджувати, що достовірні відмінності у середніх значеннях вираженості особистісних факторів у досліджуваних з різним соціометричним статусом в класі виявлені у відношенні «иіннісного відношення до справ, обов'язків та інших людей» $(\mathrm{p}<0,05)$ та «морально-ијіннісного відношення» $(\mathrm{p}<0,05)$.

Детальний аналіз табличних даних дозволяє констатувати, що динаміка зміни середніх значень вираженості у молодших школярів особистісних факторів «ціннісного відношення до справ, обов'язків та інших людей» та «морально-иіннісного відношення» має лінійний характер.

Очевидним є те, що фактор «иіннісного відношення до справ, обов'язків та інших людей» найвищих середніх значень досягає у категорії молодших школярів з найвищим соціометричним статусом в класі («зірки»), демонструючи пік найнижчих середніх значень у категорії досліджуваних з найнижчим соціометричним статусом в класі («ізольовані»). Це 
означає, що значення усіх психологічних шкал, що структурно і змістовно визначають специфіку даного інтегрального особистісного фактору, лінійно зростають від категорії досліджуваних 3 найнижчим соціометричним статусом в класі до категорії досліджуваних 3 найвищим соціометричним статусом серед однолітків. Зокрема, у молодших школярів 3 найвищим соціометричним статусом в класі («зірки») у порівнянні 3 представниками 3 найнижчим соціометричним статусом в класі («ізольовані») спостерігаються достовірно вищі показники вираженості таких психологічних шкал, як «ефективність у справах», «організаторські здібності», «взаємовідносини 3 іншими дітьми», «працелюбність», «підприємливість» і «практичність». В даному випадку можна стверджувати, що 3 підвищенням соціометричного статусу в класі ставлення і відношення до праці, діяльності (наприклад, навчальної), справ, обов'язків та інших людей у молодших школярів стає більш відповідальним та утилітарним, набуваючи більш усвідомленого і ціннісного характеру. Змістовно проінтерпретуємо виявлену закономірність.

У молодших школярів залежно від статусу в класі соціалізація відбувається у взаємозв'язку із поняттям вихованості, яке включає в себе наступні види установок: ставлення до навчання (цікавість), ставлення до праці, дбайливе ставлення до природи, ставлення до школи, ставлення до краси (естетичне ставлення), ставлення до себе. Соціальна адаптивність передбачає акцент на нормах і правилах поведінки, прийнятті цих норм, а, отже, мова йде про відповідальніше ставлення до навчальної діяльності, справ, обов'язків та інших людей. Молодші школярі із соціометричними статусами, такими як «зірки» $\mathrm{i}$ «бажані», більш відповідальні, на відміну від школярів із соціометричними статусами «ізольованих» і «відкинутих». Висока позиція в колективі однолітків, безумовно, пояснюється наявністю цінності внутрішнього потенціалу молодших школярів і розвиненою зовнішньою культурою поведінки.

Схожий характер розподілу середніх значень вираженості спостерігаємо і у відношенні особистісного фактору «морально-ціннісного відношення». Так, даний фактор найвищих середніх значень досягає у категорії молодших школярів 3 найвищим соціометричним статусом у класі («зірки»), демонструючи пік найнижчих середніх значень у категорії досліджуваних з найнижчим соціометричним статусом у класі («ізольовані»). Це свідчить про те, що значення усіх психологічних шкал, які структурно і змістовно визначають специфіку даного інтегрального особистісного фактору, лінійно зростають від категорії молодших школярів 3 найнижчим соціометричним статусом в класі до категорії молодших школярів 3 найвищим соціометричним статусом у класі. Зокрема, у молодших школярів 3 найвищим соціометричним статусом у класі («зірки») у порівнянні 3 представниками 3 найнижчим соціометричним статусом у класі («ізольовані») спостерігаються достовірно вищі показники вираженості таких психологічних шкал, як «альтруїзм», «чесність», «сумлінність», «справедливість», «терпимість», «вихованість», «освіченість», а також достовірно нижчі показники вираженості такої психологічної шкали, як «багатство» (враховуючи знак).

3 огляду на це, можна стверджувати, що з підвищенням соціометричного статусу у класі в молодших школярів стає все більш вираженою особистісна настанова оцінювати себе та інших через призму ціннісних і морально-етичних категорій i принципів. Це може свідчити про все більш виражену зорієнтованість представників 3 найвищим соціометричним статусом у класі («зірки») на морально-етичний і ціннісний імператив у своій поведінці та у ставленні до інших. Перейдемо до інтерпретації виявленої закономірності.

Встановлення дружніх зв'язків на початку періоду молодшого шкільного віку має неміцний характер. Дружні зв'язки дітей 6-7 років швидко і легко утворюються і так само швидко можуть розпадатися. Друзями діти цього віку називають тих, з ким граються, кого бачать частіше за інших.

Павелків (2015) стверджує, що діти 8-10 років в цьому плані поводяться інакше, вважаючи друзями тих, хто їм допомагає, відгукується на їхні прохання, розділяє їхні інтереси. На цьому віковому етапі дружба виникає на основі таких якостей особистості як доброта, уважність, самостійність, впевненість у собі, чесність і т.п. 
Соціометричне опитування показує, що як високий, так і низький статус учня в системі міжособистісних відносин в класі визначається цілою низкою чинників. Діти, які отримують в соціометричних опитуваннях найбільше число виборів (“зірки”), зазвичай товариські, мають хороші здібності, відрізняються ініціативністю, багатою фантазією. Важливо, що ці "зірки", як правило, добре вчаться. На іншому полюсі діти, що займають позиції знедолених. Вони також мають загальний набір характеристик: часто виявляють труднощі в спілкуванні з однолітками (забіякуваті, запальні, примхливі, грубі, замкнуті і т.п.). Серед цих дітей також є ті, для кого характерні зазнайство, жадібність, неакуратність, неохайність.

До закінчення молодшого шкільного віку, за твердженням Хлибової (2009), пріоритети більшості дітей змінюються. Школярі особливо цінують особистісні якості, серед яких вирізняються самостійність, впевненість в собі, чесність, справедливість, терпимість, вихованість. При цьому показники навчальної успішності при оцінці соціального статусу виявляються маловажливими. Діти, що мають низький статус в середовищі однолітків, характеризуються ними як суспільно пасивні, недобросовісно відносяться до праці, до чужих речей.

Молодші школярі з високим соціальним статусом у класі цілеспрямовані в своїй взаємодії з однолітками. У них все частіше починає спостерігатися кооперація та інші види просоціальної поведінки. Вони частіше проявляють альтруїзм і схильність ділитися. Вони починають краще розуміти мотиви і наміри інших людей, в результаті їх спілкування один 3 одним стає більш ефективним і значимим. Молодший шкільний вік (за Бехом (2009)) виявляється сприятливим щодо виховання у дитини фундаментального для іiі морального розвитку новоутворення, яким є здібність цінувати особистість людини. Саме тому у дітей, що займають високий соціальний статус серед однолітків, достовірно нижчі показники вираженості такої психологічної шкали, як «багатство» (враховуючи знак). Це свідчить про зорієнтованість представників з найвищим соціометричним статусом у класі на моральноетичні цінності у поведінці.

Висновки і перспективи подальших розвідок. Результати дослідження засвідчили, що відмінності у середніх значеннях вираженості особистісних факторів у молодших школярів з різним соціометричним статусом в класі виявлені у відношенні «ціннісного відношення до справ, обов'язків та інших людей» та «морально-ціннісного відношення». А саме, з підвищенням соціометричного статусу у класі у молодших школярів стає все більш вираженою особистісна настанова оцінювати себе та інших через призму ціннісних i морально-етичних категорій і принципів. Подальші наші розвідки будуть присвячені вивченню стану сформованості проблем статево-специфічних та соціально-економічних особливостей прояву особистісних характеристик молодших школярів.

\section{СПИСОК ВИКОРИСТАНИХ ДЖЕРЕЛ}

1. Андреева, Г.М. (2014) Социальная психология: учеб. для высш. учеб. заведений. Москва.: Аспект Пресс.

2. Бююль, А. (2005). SPSS: искусство обработки информации. Анализ статистических данных и восстановление скрытых закономерностей. ДиаСофтЮп.

3. Коломинский, Я. Л. (2003) Социальная психология школьного класса: научно-метод. пособие для педагогов и психологов. Минск: ООО «ФУА информ».

4. Кон, И.С. (2003) Социология личности. Москва: Академический проект.

5. Мудрик, В. А. (2000) Социальная педагогика. Учебник для пед. вузов. Москва.: Академия.

6. Мухина, В. С. (2004) Возрастная психология: феноменология развития, детство, отрочество. Москва: Академия. 
7. Павелків, Р. В. (2015) Розвиток моральної свідомості та самосвідомості в молодшому шкільному віці (Дис. доктора психол. наук). Рівненський державний гуманітарний університет. Рівне.

8. Фельдштейн, Д. И. (2011) Глубинные изменения современного детства и обусловленная ими актуализация психолого-педагогических проблем развития образования. СПб.: СПб ГУП.

9. Хлыбова Е. В. (2009) Особенности социометрического статуса младших и старших подростков. Вестн. Костром. гос. ун-та. Сер. Педагогика. Психология. Социокинетика. 1, 166-169.

\title{
REFERENCES:
}

Andreeva, G.M. (2014) Social'naja psihologija: ucheb. dlja vyssh. ucheb. Zavedenij [Social psychology: college textbook for higher educational institutions]. Moskva.: Aspekt Press.

Biuiul, A. (2005). SPSS: iskusstvo obrabotki informatsyi. Analiz statisticheskikh dannykh i vosstanovleniie skrytykh zakonomernostei [Information processing art. Statistical data analysis and hidden patterns restoration] DiaSoftYup.

Kolominskij, Ja. L. (2003) Social'naja psihologija shkol'nogo klassa: nauchno metod. posobie dlja pedagogov i psihologov [Social psychology for class: instructional guide for pedagogues and psychologists]. Minsk: OOO «FUA inform».

Kon, I.S. (2003) Sociologija lichnosti [Sociology of a person]. Moskva.: Akademicheskij proekt.

Mudrik, V. A. (2000) Social'naja pedagogika. Uchebnik dlja ped. Vuzov [Social pedagogy. College textbook for pedagogical universities]. Moskva.: Akademija.

Mukhina, V. S. Vozrastnaia psykholohiia: fenomenolohiia razvitiia, detstvo, otrochestvo [Developmental psychology: development phenomenology, childhood, adolescence] Moskva: Akademiia.

Pavelkiv, R.V. (2015) Rozvytok moralnoi svidomosti ta samosvidomosti v molodshomu shkilnomu vitsi (Dys. doktora psykhol. nauk) [Moral consciousness and self-consciousness development in junior schoolchild's age (psychological sciences doctor thesis) ] Rivnenskyi derzhavnyi humanitarnyi universytet. Rivne.

Fel'dshtejn, D. I. (2011) Glubinnye izmenenija sovremennogo Detstva i obuslovlennaja imi aktualizacija psihologo-pedagogicheskih problem razvitija obrazovanija [Significant changes of modern Childhood and foregrounding of psychological and pedagogical issues dealing with education development and caused with mentioned changes]. SPb.: SPb GUP.

Hlybova E. V. (2009) Osobennosti sociometricheskogo statusa mladshih i starshih podrostkov [Special features of sociometric status of primary and early adulhood]. Vestn. Kostrom. gos. un-ta. Ser. Pedagogika. Psihologija. Sociokinetika. 1, 166-169.

\section{SPECIAL BEHAVIOUR FEATURES OF PRIMARY SCHOOLCHILDREN'S PERSONAL CHARACTERISTICS DEPENDING ON SOCIOMETRIC STATUS IN A CLASS}

Ivanna Khomych Lecturer of the Development and Pedagogical Psychology Department of Rivne State University for the Humanities DOI https://doi.org/10.35619/praprv.v1i15.198

\begin{abstract}
The paper deals with the research of primary schoolchildren's behavior in the aspect of moral characteristics expression depending on sociometrical status in a class considering scientific approaches to researched issue. Within the experiment the author verified a hypothesis concerning with a probable influence of defined grouping alternant (sociometric status in a class) on the expressiveness level of integral personal factors of primary schoolchildren including the factors of moral and values-based attitude and values-based attitude to the affairs, duties and other people. Mentioned factors reach the highest average indicators in the category of primary schoolchildren with high sociometric status in the class ("stars"), demonstrating the top of the
\end{abstract}


lowest average indicators in the category of researched ones with low sociometric status in the class ("isolated"). The study covers that the indicators of all psychological scales linearly increases from the researched category with those who have the lowest sociometric status in the class to the researched category of ones who are with the highest sociometric status. These psychological scales denote special features for data dealing with integral personal factors in the structural and informative ways. The author highlights that these results reveal the focusing on moral and ethical values in a behavior for those who are with the highest sociometric status in the class. In a system of relations with coevals a child develops the whole range of feelings that characterize his or her as an already socialized person who aims to self-affirmation and competition with others obtaining certain status in a group. Primary schoolchildren with sociometric statuses of "stars" and "wished" are more responsible apart from those who have sociometric statuses of "isolated" and "rejected". The author presents the own interpretation of high position in a team among coevals. This position concerns with the values of primary schoolchildren's internal potential and developed external culture of behavior.

Keywords: primary schoolchild, personal characteristics, sociometric status, personal factors, moral standards, moral-and values-based attitude, values-based attitude to the affairs.

Стаття надійила до редакиії . 2020 р. 